\title{
Izabela Florczak
}

\section{Marta Otto}

\section{Uniwersalizm postanowień Europejskiego Filaru Praw Socjalnych w zakresie sprawiedliwych warunków pracy}

\section{- realny kierunek zmian czy fantasmagoria? Zagadnienia wybrane}

\begin{abstract}
Europejski Filar Praw Socjalnych koncentruje szereg swoich regulacji wokół uczciwych warunków zatrudnienia. Dotychczasowy dorobek prawodawstwa unijnego gwarantował wiele praw w tym zakresie, nie wydaje się jednak, aby ich realizacja była wystarczająca. W świetle powyższego zasadne staje się zidentyfikowanie wyzwań stojących przed prawodawcą unijnym jak i krajowym w kontekście zabezpieczenia stosownego poziomu uczciwych warunków zatrudnienia.
\end{abstract}

Obszar: Europejski Filar Praw Socjalnych - efektywne narzędzie procesu integracji społecznej czy działanie z zakresu public relations?

\section{Wprowadzenie}

Europejski Filar Praw Socjalnych zawiera szereg wytycznych związanych ze sprawiedliwymi warunkami pracy, które zasadniczo powinny stanowić wspólną podstawę polityki zatrudnienia i polityki społecznej w UE. Z punktu widzenia prawodawcy europejskiego kluczowe znaczenie dla ukonstytuowania społecznego wymiary Europy w tym obszarze ma konwergencja w zakresie bezpiecznego/pewnego i elastycznego zatrudnienia, wynagrodzeń, informowania o warunkach zatrudnienia i ochrona w przypadku zwolnień, dialogu społecznego i zaangażowania pracowników, równowagi między życiem zawodowym a prywatnym, czy w końcu zdrowego, bezpiecznego i dobrze dostosowanego środowiska pracy, a także ochrony danych.

Ze względu na widoczną dywergencję systemów prawnych w obszarze szeroko rozumianej polityki społecznej, nie jest możliwa wyczerpująca ocena możliwości realizacji postanowień Filaru w obszarze sprawiedliwych warunków pracy. Uznając Filar za akt o charakterze uniwersalnym, zasadnym wydaje się niemniej jednak choćby fragmentaryczne 
określenie, na ile, w odniesieniu do warunków zatrudnienia, ów uniwersalizm jest realnie osiągalny, a na ile pozostaje złudzeniem, fantasmagorią. Przedstawiona poniżej ocena ograniczona zostanie przy tym do wybranych jedynie komponentów II rozdziału Filaru, co więcej oparta zostanie w przeważającej mierze o stosowne standardy krajowe.

\section{Bezpieczne i elastyczne zatrudnienie}

Globalizacja i postępująca cyfryzacja radykalnie zmieniły oblicze i zasady działania współczesnych rynków pracy. Na dzisiejszym bardzo zróżnicowanym, a w konsekwencji i spolaryzowanym rynku pracy, zdefiniowanie praw i wypracowanie mechanizmów ochrony osób zatrudnionych w ramach niestandardowych (niepracowniczych) form stanowi jedno z poważniejszych wyzwań prawa pracy, którego wagę dostrzega od dłuższego czasu również unijny prawodawca. Współczesny model rynku pracy, łączący w sobie idee bezpieczeństwa i elastyczności w zatrudnieniu, promowany jest na forum unijnym od przeszło dekady ${ }^{1}$. Wprowadzony w ramach Europejskiego Filaru Praw Socjalnych (EFPS), punkt „Bezpieczne i elastyczne zatrudnienie" stanowi swoistego rodzaju odzwierciedlenie propagowanej koncepcji ,flexicurity", co do zasady opierającej się na trzech filarach, tj. elastycznym rynku pracy, hojnym systemie socjalnym i aktywnej polityce rynku pracy. Co ciekawe, w ramach EFPS, poszczególne komponenty modelu zostały częściowo rozparcelowane pomiędzy dwa punkty (vide pkt.: Aktywne wsparcie na rzecz zatrudnienia), wchodzące w skład odrębnych rozdziałów: tj. Równość szans i dostęp do zatrudnienia, Sprawiedliwe warunki pracy. Sama koncepcja bezpiecznego zatrudnienia osadzona jest przy tym w głównej mierze na zapewnieniu sprawiedliwego i równego traktowania w odniesieniu do warunków pracy, dostępu do ochrony socjalnej i szkoleń, niezależnie od rodzaju i czasu trwania stosunku pracy.

Co do zasady, EFPS autoryzuje elastyczność niezbędną do szybkiego dostosowania się pracodawców do zmian w kontekście gospodarczym, a także uznaje znaczenie wspierania pojawiających się modeli biznesowych, innowacyjnych form pracy, przedsiębiorczości czy samozatrudnienia, niemniej jednak wyznacza równocześnie swoistego rodzaju ramy/granice elastyczności, w postaci, wykraczającego poza dorobek unijny, zakazu nadużyć

\footnotetext{
${ }^{1}$ Szerzej: M. Otto, I. Florczak, Precarious work and labour regulation in the EU: current reality and perspectives, [w:] J. Kener, M.Otto, I. Florczak (red.), Precarious work. The challenge for labour law in Europe (Edward Elgar Publishing, 2019), w druku.
} 
związanych ze stosunkiem pracy prowadzących do niekorzystnych warunków pracy (w tym w drodze zakazu nadużywania nietypowych umów) ${ }^{2}$.

W Polsce, pomimo wzrostu w ostatnich latach zatrudnienia w nietypowych formach, nadal dominuje tradycyjny model pracy ${ }^{3}$, co w dużej mierze wynika z niechętnego stosunku dużej części społeczeństwa do zatrudnienia odbiegającego od klasycznego, pracowniczego wzorca kojarzonego z bezpieczeństwem socjalnym i wyższymi płacami. Dokonane dotychczas zmiany w prawie pracy tylko częściowo odpowiadają na potrzeby współczesnego rynku pracy, a w konsekwencji na możliwość indukowania niezbędnej dla efektywnego wdrożenia modelu flexicurity zmiany światopoglądowej Polaków. W pełni zasadne, w świetle powyższego, wydaje się przy tym proponowane w literaturze przedmiotu ,przejście od modelu ochrony miejsca pracy do modelu ochrony zatrudnienia w perspektywie całego życia"4. Redefiniowanie obowiązującego modelu w kierunku wykształcenia prawa zatrudnienia, co do zasady obejmującego wszystkie osoby fizyczne wykonujące $\mathrm{w}$ różnych formach pracę za wynagrodzeniem, powinno pociągnąć za sobą modyfikację/uelastycznienie ochrony pracowniczej (m.in. skrócenie okresu wypowiedzenia, zmianę pracy etatowej na zadaniową, uelastycznienie godzin pracy).

Liberalizacja prawa pracy i przejście w stronę modelu ochrony zatrudnienia to jednak nie jedyny problem w Polsce. Stabilne zatrudnienie i zabezpieczenie socjalne to w modelu flexicurity także kompleksowe wsparcie i wyposażenie pracownika w takie umiejętności i kwalifikacje, które ułatwią mu szybki powrót na rynek pracy na każdym etapie życia zawodowego. Istotną rolę $\mathrm{w}$ tym względzie ma do odegrania trzeci komponent duńskiego złotego trójkąta, a mianowicie aktywna polityka rynku pracy, realizowana przez służby zatrudnienia. W Polsce, pomimo bogatego instrumentarium przewidzianego $\mathrm{w}$ ustawie o promocji zatrudnienia i instytucjach rynku pracy, problemem pozostają nie tylko wciąż relatywnie niskie w skali europejskiej nakłady przeznaczane na prowadzenie aktywnej polityki rynku pracy, ale także efektywność ich wydatkowania ${ }^{5}$. Co do zasady, środki te powinny być dokładnie profilowane, adresowane do bezrobotnych $\mathrm{z}$ tzw. grup problemowych (m.in. młodych matek, osób w wieku okołoemerytalnym, osób długotrwale bezrobotnych),

\footnotetext{
2 Por. Dokument Roboczy Służb Komisji towarzyszący dokumentowi Komunikat Komisji Do Parlamentu Europejskiego, Rady, Europejskiego Komitetu Ekonomiczno-Społecznego i Komitetu Regionów.

Ustanowienie Europejskiego Filaru Praw Socjalnych \{COM(2017) 250 final\}, s. 23-28.

${ }^{3} \mathrm{https} / /$ stat.gov.pl/files/gfx/portalinformacyjny/pl/defaultaktualnosci/5475/21/1/1/notatka_nietypowe_formy_zat rudnienia_2016_01_27.pdf. Dostęp: 2.2.2019.

4 M. Szylko-Skoczny, Zmiany w modelu pracy, Uniwersytet Warszawski, $\quad$ s. 182 https://www.ue.katowice.pl/fileadmin/_migrated/content_uploads/17_M.Szylko-

Skoczny_Zmiany_w_modelu_pracy.p_df. [Dostęp: 2.2.2019].

${ }^{5}$ Por. Z. Wiśniewski, K. Zawadzki, Efektywność polityki rynku pracy w Polsce, Toruń 2011, s. 35
} 
a ich efektywność powinna podlegać systematycznej ewaluacji. Zasadne wydaje się przy tym ograniczenie skali środków przeznaczanych na instrumenty najmniej efektywne (m.in. roboty publiczne) i skierowanie większych nakładów na narzędzia podwyższające poziom kapitału ludzkiego, takie jak doradztwo czy szkolenia, czy też wprowadzenie narzędzi odpowiadających specyfice bezrobocia w Polsce, m.in. tzw. subsydiów relokacyjnych zwiększających mobilność geograficzną bezrobotnych; czy grantów na promowane przez unijnego prawodawcę samozatrudnienie ${ }^{6}$. Powyższe założenia nie zostaną spełnione bez odpowiednich nakładów finansowych na aktywne formy walki z bezrobociem. Obecnie, zarówno w skali globalnej, jak i na poziomie krajowym, finansowanie aktywnych form walki $\mathrm{z}$ bezrobociem jest dramatycznie niskie ${ }^{7}$.

\section{Ochrona wynagrodzenia}

Kluczem dla odkodowania norm wynikających z zasady Filaru obejmującej swoim zakresem ochronę wynagrodzenia jest prawidłowe określenie jej zakresu podmiotowego. Prawodawca unijny posługuje się pojęciem worker, tłumaczonym w polskim przekładzie na ,pracownik”8. Tłumaczenie to jest błędne. Zakres desygnatów pojęcia worker jest szerszy, dlatego też poniższa analiza opierać się będzie na anglojęzycznym brzmieniu zasady nr 6 z kategorii 2.

Europejski Filar nie ma za zadanie wprowadzenia jednolitych rozwiązań w zakresie wysokości wynagrodzenia za pracę. Wyznacza on jednak kierunki, którym powinni podążać ustawodawcy i partnerzy społeczni ustalając wysokość wynagrodzenia. Osobom zatrudnionym powinno być wypłacane wynagrodzenie godziwe, zapewniające godziwe warunki życia. „Godziwość” nie może być jednak oderwana od realiów konkretnego państwa członkowskiego. Nie powinna być ona zatem określana jako uśredniony standard życia godziwego na poziomie UE, a jako godziwość życia w warunkach właściwych dla danego kraju. Taki stan rzeczy wynika przede wszystkim z wyłączenia, mocą art. 153 TFUE, spod działalności prawodawczej

\footnotetext{
${ }^{6}$ M. Guzikowski, Celowość wprowadzenia koncepcji flexicurity w Polsce, Optimum. Studia Ekonomiczne 2016 nr 1 (79) s. 143.

${ }^{7}$ Por. B. Surdykowska, Umowa o pracę na czas nieokreślony jako podstawa bezpieczeństwa socjalnego - kilka refleksji, [w:] Nauka i praktyka w stużbie czlowiekowi pracy: umowy terminowe, A. Musiała (red.), Poznań 2018, s. 210-211. Autorka podaje, że w Polsce na szkolenia dla bezrobotnych wydatkuje się zaledwie 0,01 PKB podkreślając, że przy takim rozłożeniu nakładów finansowych nigdy nie zostanie osiągnięty zadowalający poziom bezpieczeństwa socjalnego.

${ }^{8} \mathrm{Na}$ wątpliwości związane z wyznaczeniem desygnatów pojęcia „worker" na gruncie Filaru uwagę zwraca B. Surdykowska, Europejski Filar Praw Socjalnych - próba sprostania wielorakim wyzwaniom stojacym przed Uniq Europejską, PiZS 2017 nr 11, s. 4
} 
UE obszarów związanych $\mathrm{z}$ wynagrodzeniem za pracę. Nie oznacza to jednak braku jakiegokolwiek wpływu na kształtowanie zasad związanych z określaniem wynagrodzenia za pracę. Postulat godziwości wynagrodzenia za pracę wyrażony jest również w (Zrewidowanej) Europejskiej Karcie Społecznej, zatem zdecydowanie można mu przypisywać charakter postulatu ponadnarodowego.

Omawiana zasada przyznaje również prawo do minimalnego wynagrodzenia za pracę, którego wysokość powinna być ustalana, o czym Filar wyraźnie stanowi, z uwzględnieniem krajowej sytuacji społecznej i gospodarczej. Ważnym postulatem jest ponadto, aby ochrona finansowa aktualizowana $\mathrm{w}$ sytuacjach pozostawania bez pracy gwarantowała godne życie, ale nie stanowiła bodźca zachęcającego do braku aktywności zawodowej. Jest to zgodne z ogólnym przesłaniem Filaru, który łączy zapewnianie bezpieczeństwa socjalnego z jak najszerszym zatrudnieniem, w tym zatrudnieniem grup uważanych za wykluczone - osób z niepełnosprawnościami, osób młodych ${ }^{9}$, osób starszych czy kobiet.

Postanowienia Filaru postulują, aby zapobiegać ubóstwu osób pracujących. Powyższe pozostaje $\mathrm{w}$ oczywistym związku z poziomem, na którym określone zostanie minimalne wynagrodzenie za pracę. Wydaje się jednak, że postulat ten nie może być rozpatrywany bez odniesienia do innych zasad Filaru, w szczególności do zasady z kat. 3 pkt 4 - minimalny dochód. Minimalne wynagrodzenie nie przysługuje w równej wartości wszystkim pracującym - jest zróżnicowane w zależności od ilości pracy, jaka została wykonana (zazwyczaj od wielkości etatu). Tym samym może mieć miejsce sytuacja, w której dana osoba, pomimo aktywności zawodowej, będzie pozostawała osobą ubogą z uwagi na pracę w zbyt niskim wymiarze. Aby w takich sytuacjach zapobiegać ubóstwu, powinno być przyznane prawo do otrzymywania pomocy finansowej. Zapewnia to właśnie zasada gwarantująca minimalny dochód, zgodnie z którą ,wszystkie osoby pozbawione wystarczających środków mają prawo do odpowiednich świadczeń związanych $\mathrm{z}$ dochodem minimalnym zapewniających godne życie (...)".

Ostatni z punktów omawianej zasady odnosi się do sposobu ustalania wynagrodzenia za pracę, który powinien być przejrzysty i przewidywalny oraz uwzględniać autonomię partnerów społecznych. W tym przypadku Filar nie nawiązuje w swej treści do sposobu określania wyłącznie minimalnego wynagrodzenia za pracę. Omawiana zasada dotyczy sposobu ustalania każdego wynagrodzenia za pracę. Przejrzystość i przewidywalność, jako czynniki występujące przy określaniu wysokości wynagrodzenia, spełniają dwie zasadnicze

\footnotetext{
${ }^{9}$ O postanowieniach Filaru w odniesieniu do osób młodych M. Szymański, Europejski Filar Praw Socjalnych wobec młodych osób na rynku pracy w Europie, Monitor Prawa Pracy 2018 nr 7, s. 21-26.
} 
role. Pozwalają określić, czy wynagrodzenie nie zostało ustalone w sposób dyskryminujący, zgodnie z zasadą równości szans oraz dają osobom zatrudnionym poczucie bezpieczeństwa socjalnego.

Określenie stopnia aplikacyjności omawianej zasady jest zróżnicowane w zależności od stanu dialogu społecznego w poszczególnych państwach członkowskich. Dla przykładu warto zwrócić uwagę na sytuację w Polsce. W styczniu 2019 r. obradował zespół problemowy Rady Dialogu Społecznego ds. budżetu, wynagrodzeń i świadczeń socjalnych ${ }^{10}$, który prowadzi prace nad zmianą ustawy o minimalnym wynagrodzeniu za pracę.

Czy można zatem stwierdzić, że w Polsce dialog społeczny w zakresie minimalnego wynagrodzenia działa bez zarzutu? Aby odpowiedzieć na to pytanie należy odnieść się do art. 2 ust. 5 ustawy o minimalnym wynagrodzeniu za pracę ${ }^{11}$, zgodnie z którym jeżeli Rada Dialogu Społecznego nie uzgodni w określonym terminie wysokości minimalnego wynagrodzenia w roku następnym oraz nie ustali wysokości minimalnej stawki godzinowej w roku następnym, Rada Ministrów ustala, w drodze rozporządzenia, w terminie do dnia 15 września każdego roku, wysokość minimalnego wynagrodzenia w roku następnym, a także wysokość minimalnej stawki godzinowej w roku następnym wraz z terminem zmiany tych wysokości. Tym samym, po prześledzeniu sposobu ustalanie minimalnego wynagrodzenia za pracę jasne będzie, czy partnerzy społeczni dochodzili w tym względzie do porozumienia. Minimalne wynagrodzenie za pracę obowiązujące w 2019 r. zostało określone ${ }^{12}$ w trybie art. 5 ust. 2 (bez porozumienia partnerów społecznych). Taki sam tryb stosowano w latach 2004-2018 z uwzględnieniem zastąpienia Komisji Trójstronnej Radą Dialogu Społecznego ${ }^{13}$. Powyższe jednoznacznie pokazuje, że na gruncie realiów krajowych dialog społeczny ukierunkowany na ustalanie minimalnego wynagrodzenia jest mrzonką.

Istotną kwestią, dostrzegalną na poziomie krajowym, są dodatkowo podstawy prawne zatrudnienia, które nie gwarantują dochodu minimalnego. Jedną z grup, której nie jest gwarantowane wynagrodzenie na poziomie minimalnym są młodociani w okresie nauki zawodu. Zgodnie z obowiązującą obecnie stawką, ustalaną na podstawie rozporządzenia Rady Ministrów z 28.5.1996 r. $\quad$ w sprawie przygotowania zawodowego młodocianych

\footnotetext{
${ }^{10} \mathrm{http}: / / w w w . d i a l o g . g o v . p l / a k t u a l n o s c i / a r t, 1027$,posiedzenie-zespolu-problemowego-rds-ds-budzetuwynagrodzen-i-swiadczen-socjalnych.html, [Dostęp: 30.1.2019].

${ }^{11}$ Ustawa z 10.10.2002 r. o minimalnym wynagrodzeniu za pracę (t.j. Dz. U. z 2018 r. poz. 2177).

${ }^{12}$ Rozporządzenie RM z 11.9.2018 r. w sprawie wysokości minimalnego wynagrodzenia za pracę oraz wysokości minimalnej stawki godzinowej w 2019 r. (Dz. U. poz. 1794).

13 Ustawa z 24.7.2015 r. o Radzie Dialogu Społecznego i innych instytucjach dialogu społecznego (t.j. Dz. U. z 2018 r. poz. 2232 z późn. zm.).
} 
i ich wynagradzania ${ }^{14}$, wynagrodzenie takie wynosi, odpowiedni w I, II i III roku nauki 183,21 zł, 229,01 zł i 274,81 zł. Wynagrodzenie powinno spełniać funkcję alimentarną, gwarantującą m.in. możliwość zaspokojenia podstawowych potrzeb na odpowiednim poziomie. Osoby młodociane zazwyczaj pozostają we wspólnym gospodarstwie domowym ze swoimi rodzicami, dlatego też uzasadnione wydaje się przyznanie im wynagrodzenia o raczej symbolicznym charakterze. Na równi ze świadczeniem pracy jako takiej osoby te pobierają bowiem naukę. Inaczej należałoby się odnieść do wysokości wynagrodzenia przyznawanego stażyście, odbywającego staż na podstawie ustawy o promocji zatrudnienia i instytucjach rynku pracy $^{15}$. Staż oznacza co prawda nabywanie przez bezrobotnego umiejętności praktycznych do wykonywania pracy, czyli jest połączony z nauką, ale wykonują go osoby z założenia samodzielne życiowo. Dlatego też wysokość przyznawanego im wynagrodzenia nie powinna odbiegać od wynagrodzenia należnego pracownikom. Istniejąca obecnie dysproporcja W należnym wynagrodzeniu nie koresponduje z omawianą zasadą. Wyjątki od niej powinny być aksjologicznie uzasadniane, jak choćby poprzez dowiedzenie, że określona grupa osób pracujących ma mniejsze potrzeby związane z wydatkowaniem wynagrodzenia.

\section{Informowanie o warunkach zatrudnienia i ochrona w przypadku zwolnień}

Stabilizacja socjalna osób zatrudnionych związana jest $\mathrm{z}$ pewnością $\mathrm{w}$ zakresie warunków świadczenia pracy. Wiedzę o tym ma prawodawca unijny, czego wyrazem jest zasada $7 \mathrm{w}$ kat. 2 EFPS, uznana za jedną z priorytetowych ${ }^{16}$. Zgodnie $\mathrm{z}$ jej treścią przy zatrudnieniu osoby zatrudnione ${ }^{17}$ mają prawo otrzymywać informacje w formie pisemnej dotyczące ich praw i obowiązków wynikających ze stosunku pracy, w tym okresu próbnego. Druga część zasady stanowi o obowiązku poinformowania osoby zatrudnionej przed zwolnieniem na temat powodów zwolnienia oraz przyznania jej rozsądnego okres wypowiedzenia. Ponadto osoby zatrudnione mają prawo dostępu do skutecznego i bezstronnego rozwiązywania sporów, a w przypadku nieuzasadnionego zwolnienia mają prawo do dochodzenia roszczeń, w tym do odpowiedniego odszkodowania.

\footnotetext{
14 t.j. Dz. U. z 2018 r. poz. 2010.

${ }^{15}$ Ustawa z 20.4.2004 r. o promocji zatrudnienia i instytucjach rynku pracy (t.j. Dz. U. z 2018 r. poz. 1265 z późn. zm.).

${ }^{16}$ S. Rainone, The Social Pillar and its Implementation - Is a More Social Europe with Less Burdens on Employers Really Possible?, http://elw-network.eu/wp-content/uploads/2018/03/RAINONE1.pdf, s. 2, [Dostęp: 30.1.2019].

${ }^{17} \mathrm{~W}$ polskiej wersji ,,pracownicy”. Dotyczy to całej treści omawianej zasady.
} 
Powyższe kwestie, w odniesieniu do obowiązków informacyjnych, stały się na tyle istotne, że Komisja Europejska pracuje nad projektem Dyrektywa Parlamentu Europejskiego i Rady w sprawie przejrzystych i przewidywalnych warunków pracy w Unii Europejskiej ${ }^{18}$. Zgodnie z uzasadnieniem do projektu inicjatywa ta stanowi jedno z najważniejszych działań Komisji stanowiących nawiązanie do Europejskiego Filaru Praw Socjalnych. Jak wskazują projektodawcy Filar wyznacza kierunki działań służących wspieraniu odnowionej pozytywnej konwergencji w zakresie norm zabezpieczenia społecznego w kontekście zmieniającej się sytuacji na rynku pracy. Projekt dyrektywy jest pochodną ustaleń, których dokonano na etapie prac nad filarem, takich jak:

1) istnienie rozbieżności pomiędzy obecnym dorobkiem unijnym w zakresie praw socjalnych a zmianami zachodzącymi na rynku pracy;

2) istnienie luk w ochronie pracowników;

3) potrzeba podjęcia działań na szczeblu unijnym w celu stworzenia ram dla uczciwych warunków pracy i zapewnienia równowagi między elastycznością a pewnością prawa. W zakresie omawianej zasady, w części dotyczącej informowania o warunkach zatrudnienia, Filar spełnia swoje systemowe założenie - wyznacza kierunki dalszych, skonkretyzowanych działań prawodawczych. Warto bowiem zauważyć, że zgodnie z uzasadnieniem do projektu ogólnym celem proponowanej dyrektywy jest promowanie bezpieczniejszego i bardziej przewidywalnego zatrudnienia, a równocześnie zapewnienie zdolności adaptacji rynku pracy i poprawa warunków życia i pracy. Aby w pełni uznać założenia Filaru za spełnione dyrektywa musi jednak zostać uchwalona. Warto przy tym zauważyć, że jej projekt datowany jest na grudzień 2017 roku.

Dalsze prace prawodawcze powinny zostać ponadto podjęte w odniesieniu do drugiej części składowej omawianej zasady - ochrony w wypadku zwolnień. Projekt wzmiankowanej powyżej dyrektywy nie obejmuje swoim zakresem przedmiotowym tych kwestii, na horyzoncie nie klarują się inne dokumenty mające ją normować w sposób bardziej szczegółowy, aniżeli czyni to Filar. Z braku skonkretyzowanych środków zaradczych warto jedynie wskazać, że postulaty zawarte w Filarze, odnoszące się do ochrony w wypadku zwolnień, są jak najbardziej możliwe do realizacji na poziomie poszczególnych krajów członkowskich. Rozpatrując to zagadnienie z punktu widzenia krajowego stanu prawnego warto jednak wskazać, że de lege lata uzasadnienia wymaga wypowiedzenie wyłącznie umowy o pracę na czas nieokreślony. Tym samym umowy terminowe wypowiadane są z pominięciem zasad

\footnotetext{
${ }^{18} \mathrm{COM} / 2017 / 0797$ final - 2017/0355 (COD).
} 
określonych w Filarze. Krajowy porządek prawny różnicuje również, w zależności od rodzaju umowy o pracę, uprawnienia przyznawane pracownikom w wieku przedemerytalnym, związane z wypowiedzeniem umów z naruszeniem przepisów. Zwrócił na to uwagę Trybunał Konstytucyjny w wyroku z 11.12.2018 r. ${ }^{19}$. Tym samym polski ustawodawca ma przed sobą kolejne wyzwania legislacyjne, których celem jest zapewnienie jak najszerszej ochrony związanej z wypowiadaniem umów o pracę.

Dyskusyjna może być również realizacja prawa do ochrony roszczeń w przypadku nieuzasadnionego zwolnienia. Nie chodzi bowiem o sam fakt możliwości wystąpienia na drogę pozasądową i sądową, ale o długość trwania tego typu postępowań, która znacząco negatywnie wpływa na możliwość uznania obecnie obowiązujących środków za dostatecznie skuteczne.

\section{Zdrowe, bezpieczne i odpowiednio dostosowane środowisko pracy}

Pierwszy z komponentów omawianej zasady przyznaje osobom zatrudnionym prawo do wysokiego poziomu ochrony ich bezpieczeństwa i higieny pracy. Tym, co różnicuje postanowienia Filaru względem dotychczasowego kierunku działań struktur unijnych, jest skupienie się na zapewnianiu „wysokiego” poziomu ochrony. Podejmowane wcześniej aktywności wyznaczały kierunki mające zapewniać ochronę na poziomie „minimalnym”. Kierunek zmian wydaje się słuszny, jednakże ich realizacja może być w praktyce bardzo trudna bądź wręcz niemożliwa. W jaki bowiem sposób różnicować poziomy ochrony, stosując gradację rozciągającą się od ochrony minimalnej do wysokiej? Czy ochrona wysoka oznacza ochronę graniczną, przy zastosowaniu której wyczerpano dostępne środki? W jaki sposób powinno się oceniać dostępność tych środków: w odniesieniu do poziomu ochrony w danym państwie, czy powinno się może stosować wzorzec uniwersalny?

Wątpliwości wpływających na możliwość skutecznej realizacji omawianego postulatu jest wiele, co nie wpływa negatywnie na jego ocenę. Sama refleksja opierająca się na stawianiu pytania „czy konkretną ochronę można jeszcze rozszerzyć?” zdaje się realizować wskazany przez Filar kierunek dążenia do zapewnienia ochrony na możliwie jak najwyższym poziomie.

Drugi komponent omawianej zasady koncentruje się na przyznaniu osobom zatrudnionym prawa do środowiska pracy dostosowanego do ich potrzeb zawodowych, które umożliwia im przedłużenie uczestnictwa w rynku pracy. W zasadzie tej, jak określono w dokumencie roboczym służby komisji towarzyszącym wydaniu Filaru ${ }^{20}$, wprowadzono dwa

\footnotetext{
${ }^{19}$ P 133/15, LEX nr 2590235.

${ }^{20}$ SWD (2017) 201 final.
} 
powiązane wzajemnie prawa. Pierwsze z nich wykracza poza ochronę zdrowia i bezpieczeństwa dzięki przyznaniu pracownikom prawa do środowiska pracy dostosowanego do ich szczególnych okoliczności zawodowych. Drugie z przyznanych praw, pozostające W zgodzie z zasadą aktywnego starzenia się, uznaje potrzebę dostosowania środowiska pracy tak, aby umożliwić pracownikom zrównoważoną i dłuższą karierę zawodową. Jako konkretyzację powyższego prawa wskazano, że niektóre przystosowania, takie jak np. lepsze oświetlenie przy wykonywaniu pracy urzędniczej, mogą być konieczne z uwagi na wiek pracownika. Omawiana zasada Filaru odzwierciedla jedną z głównych jego cech kompleksowość. Poszczególne postulatu zawarte w tym dokumencie nie mają racji bytu bez odnoszenia ich do pozostałych wyznaczanych kierunków polityki społecznej Unii Europejskiej.

Możliwość wdrożenia omawianego komponentu zasady związanej z odpowiednim dostosowaniem środowiska pracy jest realna i możliwa do osiągnięcia w poszczególnych krajach członkowskich. Wymaga jednak zaangażowania partnerów społecznych $\mathrm{w}$ takie kreowanie rynku pracy w taki sposób, aby umożliwiał aktywność zawodową również tych pracowników, którzy z racji wieku mają szczególne potrzeby i obniżone możliwości pracy. Całkowite wykluczanie ich z rynku pracy nie jest zjawiskiem pożądanym, ale możliwym do wystąpienia w związku ze procesem starzenia się społeczeństwa. Co więcej, Filar podkreśla, że osoba zatrudniona, która w toku kariery zawodowej pracowała w dobrych, dostosowanych warunkach pracy, dłużej zachowuje zdolności do aktywności na wysokim poziomie.

Dotąd w polskich realiach zwracano głównie uwagę na konieczność dostosowywania środowiska pracy dla potrzeb osób niepełnosprawnych. Nie oznacza to jednak, że wysuwane w tym zakresie postulaty uznać można za wypełnione ${ }^{21}$. Prowadzone dalsze prace legislacyjne powinny wciąż obejmować kwestie związane $\mathrm{z}$ zapewnianiem osobom z niepełnosprawnościami dostosowanych do ich potrzeb miejsc pracy, wykraczając przy tym swoim zakresem poza nakierowanie na specjalne potrzeby wyłącznie tej grupy.

\section{Ochrona danych}

Równolegle z prawem do bezpiecznego i odpowiednio dostosowanego środowiska pracy uregulowano prawo pracowników (osób zatrudnionych) do ochrony ich danych osobowych w kontekście zatrudnienia. Ochrona danych osobowych w miejscu pracy jest

\footnotetext{
21 Por. B. Surdykowska, Racjonalne dostosowanie stanowiska pracy do potrzeb ogótu zatrudnionych czy Europejski Filar Praw Socjalnych może stanowić inspirację? Dialog 2017 nr 3, s. 23-24.
} 
współcześnie jednym z bardziej newralgicznych obszarów regulacyjnych. Postępująca dematerializacja i destandaryzacja pracy implikuje nieuchronne zmiany w sferze prerogatyw pracodawców, w konsekwencji tworząc nowy wymiar podporządkowania pracowniczego, który stawia pod znakiem zapytania wyraźną niegdyś separację pomiędzy życiem zawodowym a prywatnym pracowników.

Najbardziej problematyczna obecnie wydaje się ogólna tendencja w kierunku rozszerzania roli danych osobowych w zatrudnieniu ze stosunkowo ograniczonej, tradycyjnej roli selekcji i dyscypliny, w stronę nowego zestawu funkcji implementowanych przez działy zarządzania zasobami ludzkimi (HRM), które mają związek z motywowaniem, akulturacją pracowników oraz szeroko rozumianą kontrolą ich zachowania. Te ostatnie praktyki, w parze z postępującą cyfryzacją i automatyzacją środowiska pracy, zmieniają ilościowo i jakościowo zasób informacji pozostających $\mathrm{w}$ dyspozycji pracodawców, a w rezultacie wzmacniają inherentną asymetrię pomiędzy stronami stosunku pracy. Zaaprobowanie w/w praktyk jako nieodzownych elementów kultury organizacyjnej współczesnych miejsc pracy, wydaje się przy tym wątpliwe, nie tylko z punkty widzenia tradycyjnie przyjętych granic kontroli i nadzoru pracodawców, ale także względów etycznych. Przede wszystkim, pracownicy mogą być poddani stosownym praktykom przetwarzania danych osobowych w dłuższym okresie czasu niż w większości przypadków byłoby to możliwe w innej „przestrzeni publicznej”. Aspekt ciągłości niewątpliwie ma znaczenie dla oceny stopnia ingerencji w prywatność czy godność pracownika. W związku z tym, mimo że odrębne naruszenia danych osobowych pracownika mogą wydawać się niewielkie, rozpatrywane łącznie, mogą przyczynić się do wytworzenia wrogiego środowiska pracy (hostile working environment). Włączenie w ramach EFPS problematyki ochrony danych osobowych pracowników do punktu zdrowe, bezpieczne i odpowiednio dostosowane środowisko pracy ma zatem swoje racjonalne uzasadnienie.

Co więcej, wydaje się być swoistego rodzaju potwierdzeniem wyraźnie wyodrębnionego przez Europejski Trybunał Praw Człowieka, w drodze zintegrowanego podejścia do wykładni postanowień Europejskiej Konwencji Praw Człowieka z 1950 r., społecznego wymiaru ochrony prywatności i danych osobowych pracownika. ${ }^{22} \mathrm{~W}$ gospodarce rynkowej, w której większość społeczeństwa zarabia na życie, spędzając przeważającą część swojego czasu w miejscu pracy, ochrona prywatności informacyjnej pracowników, poza wartością jednostkową, ma wyraźną wartość publiczną. Poszanowanie prawa do prywatności i ochrony danych osobowych w zatrudnieniu jest niezbędne nie tylko

\footnotetext{
${ }^{22}$ Szerzej M. Otto, The right to privacy in employment: In search of the European model of protection, European Labour Law Journal, $2015 \mathrm{nr} 4$.
} 
do efektywnego egzekwowania praw i swobód obywatelskich pracowników (vide inter alia prawo do poszanowania prywatności i życia rodzinnego, wolności myśli, sumienia i religii; przepływu informacji i wyrażania opinii; zgromadzania się i stowarzyszania się; zakaz wszelkiej dyskryminacji), ale także ich praw społecznych (prawa do pracy, prawa do należytych i sprawiedliwych warunków pracy, prawa do ochrony przed nieuzasadnionym zwolnieniem). ${ }^{23}$

W stanowiącym centralny element wielopoziomowego systemu ochrony prawa do prywatności informacyjnej jednostek w Europie ogólnym rozporządzeniu o ochronie danych osobowych (RODO), zezwala się państwom członkowskim, aby $w$ ich prawie lub w porozumieniach zbiorowych przewidziane były przepisy szczegółowe, zapewniające stosowną ochronę praw i wolności pracowników. ${ }^{24} \mathrm{~W}$ świetle dotychczasowej praktyki regulacyjnej państw członkowskich, a także judykatury europejskiej w w/w obszarze, celowym wydaje się być przeniesienie, w ramach stosownych regulacji krajowych, punktu ciężkości z ochrony, budzącej wiele wątpliwości interpretacyjnych i praktycznych, kategorii „danych osobowych pracowników” na bezpośrednią regulację poszczególnych praktyk związanych z przetwarzaniem danych osobowych pracowników takich jak np. monitorowanie poczty elektronicznej pracowników, monitoring wideo, geolokalizacja, profilowanie, przetwarzanie danych $\mathrm{w}$ procesie rekrutacji czy ujawnianie danych pracowników osobom trzecim. Proponowana zmiana optyki ustawodawczej powinna umożliwić przyjęcie bardziej adekwatnego, a jednocześnie proaktywnego podejścia regulacyjnego, który w praktyce, pozwoliłby na ustanowienie normatywnych ram prywatności informacyjnej pracownika, a także umożliwiłby identyfikację naruszeń innych wymiarów (m.in. terytorialnych czy osobowych) prywatności pracownika często towarzyszących przetwarzaniu danych, które przy tradycyjnym podejściu regulacyjnym opartym na ochronie danych osobowych są często pomijane. Równie ważne wydaje się przy tym właściwe określenie zakresu podmiotowego odpowiednich regulacji, a więc wzięcie pod uwagę struktury współczesnych rynków pracy, tj. zagwarantowanie odpowiednich standardów ochrony osobom wykonującym pracę w ramach nietypowych (niepracowniczych) form zatrudnienia.

\footnotetext{
${ }^{23}$ Szerzej M. Otto, The Right to privacy in employment: a comparative analysis, Hart Publishing, Oxford, 2016.

${ }^{24}$ Artykuł 88 Rozporządzenia PE i Rady (UE) 2016/679 z 27.4.2016 r. w sprawie ochrony osób fizycznych w związku z przetwarzaniem danych osobowych i w sprawie swobodnego przepływu takich danych oraz uchylenia dyrektywy 95/46/WE (ogólne rozporządzenie o ochronie danych) (Dz.Urz.UE.L Nr 119, str. 1).
} 


\section{Podsumowanie}

Filar stanowi niewątpliwie ważny krok w rozwoju polityki społecznej UE, $\mathrm{z}$ potencjalnymi implikacjami wkraczającymi bezpośrednio $\mathrm{w}$ obserwowalną asymetrię ekonomiczną, jak i informacyjną stron stosunku zatrudnienia. Podczas gdy cele polityki społecznej UE - jak również wartości, na których się opierają - zostały już określone w prawie traktatowym, Filar przekształca je w ,zasady”, a nierzadko 'prawa' obywateli UE. Widoczna zmiana $\mathrm{w}$ narracji nie jest jednak wystarczająca dla stworzenia uniwersalnego standardu w zakresie sprawiedliwych warunków zatrudnienia. Aby Filar był skuteczny, niezbędny jest kolejny krok: wykształcenie zarówno na poziomie UE jak i poszczególnych porządków krajowych stosownych ram instytucjonalnych gwarantujących rzeczywiste egzekwowanie ww. zasad czy praw.

Nie budzi przy tym wątpliwości fakt, że implementacja standardów w zakresie sprawiedliwych warunków pracy, nie będzie skuteczna i zrównoważona, jeżeli opierać się będzie wyłącznie na najniższym wspólnym mianowniku. Chociaż minimalne standardy są potrzebne, aby przeciwdziałać ubóstwu osób pracujących, niepewności zatrudnienia, złym warunkom pracy czy segmentacji rynku pracy, w dobie zwiększenia współczynnika towarowości pracy koniecznym wydaje się urzeczywistnienie międzynarodowych standardów na rzecz godnej pracy czy też pracy określonej jakości.

Na dzień dzisiejszy główną przeszkodą wydaje się być brak w UE własnych podatków, z których można by finansować szeroko zakrojone działania w ramach polityki społecznej. W konsekwencji możliwość sprostania wymogom Filaru zależy od danego kraju, w tym przede wszystkim przychylności władzy i poziomu dialogu społecznego.

\section{Summary}

A wide range of regulations of the European Pillar of Social Rights are focused on fair employment conditions. The hitherto achievements of EU legislation guaranteed a number of rights in this respect, yet their implementation still appears insufficient. In the light of the above, it is justified to identify the challenges that the EU and national legislator are facing in the context of securing an adequate level of fair employment conditions. 
MŁODY JURYSTA 2019/2

\section{Izabela Florczak}

Adiunkt w Katedrze Prawa Pracy, Zakładzie Prawa Ubezpieczeń Społecznych i Polityki Społecznej na Uniwersytecie Łódzkim, Koordynator Polskiej Sieci Naukowej Prawa Pracy i Zabezpieczenia Społecznego COOPERANTE, radca prawny. Autorka publikacji z zakresu indywidualnego prawa pracy dotyczących modeli zatrudnienia umownego, zatrudniania cudzoziemców, zatrudnienia prekaryjnego oraz zatrudnienia tymczasowego. Członek licznych gremiów naukowych zarówno krajowych, jak i międzynarodowych.

\section{Marta Otto}

Adiunkt w Katedrze Prawa Pracy, Zakładzie Prawa Ubezpieczeń Społecznych i Polityki Społecznej na Uniwersyteciem Łódzki, Koordynator Polskiej Sieci Naukowej Prawa Pracy i Zabezpieczenia Społecznego COOPERANTE. Członek Advisory Committee of Labour Law Research Network LLRN. Autorka publikacji z zakresu prawa pracy, w tym ochrony praw człowieka w zatrudnieniu. Brała udział w licznych międzynarodowych projektach badawczych z zakresu prawa pracy i polityki społecznej. 